\title{
WHY PEOPLE ARE THE MOST IMPORTANT FACTOR IN URBAN REGENERATION
}

\author{
Ir. Kiviet, Edgar M.A. \\ Architect RIBA, Senior Associate Director RTKL, London \\ E-mails edgar.kiviet@callisonrtkl.com
}

\begin{abstract}
Opinion article about the factors that trigger urban regeneration and the factors that make them a success or a failure. These questions are especially pertinent in Eastern Europe, where the need for a renewed economic boost in cities is even greater than in Central Europe.

One of the most important factors of success is recognising the complexity of these developments. And much like a biological ecosystem, a city's urban tissue is enormously complex, with many stakeholders, existing infrastructures, site contamination, public and private collaborations, planning procedures and financing formulas. The "human factor" being the most important one.

When redeveloping widely used civic spaces, deeply embedded in the hearts and minds of people and communities, it is imperative that urban design professionals get this right. Identifying the most important factor is the easy bit. It's making it work that's the challenge.
\end{abstract}

Keywords: Urban planning, master planning, urban regeneration, transformation, community, people. 


\section{WHY PEOPLE ARE THE MOST IMPORTANT FACTOR IN URBAN REGENERATION}

Across Europe, masterplanning and development of large-scale urban regeneration projects is at an all-time high. As an urban planning and design professional, this unstoppable and accelerated process of urbanisation is impossible to ignore. While this growth shows obvious connections to the state of cities today, it also shows new opportunities, and some challenges, for the future of centrally-located, dormant brownfield sites in these locations.

From my position at CallisonRTKL I am able to contribute to this growth as we are working on a number of significant urban regeneration developments in some of Europe's largest and most diverse cities. One of the key questions we ask ourselves in the Planning and Urban Design team is: How do we use revitalization to create successful developments in cities around the world while keeping people at the forefront of these efforts?

Cities around the world are seeing an increased awareness from the general public about the urban public realm, possibly caused by the simple fact that more people today live in cities than ever before. Additionally, frequent international travel puts these places under greater scrutiny, prompting us to compare each city with one another. This is compounded by aggressive city-by-city marketing in the media and competitive ranking that further provokes analysis and competition.

Exponential urban growth sparked by the Industrial Revolution led to numerous large mono functional industrial districts that now lay abandoned in the heart of many cities. But problem and opportunity go hand in hand, and the new economic model with its focus on services, innovation, creativity and high-skilled labour is now extremely reliant on these areas for living, leisure and working.

Suddenly, brownfield sites that were once obsolete are now are prime locations that offer secure investment and yield.

Often even before a planned transformation begins, interest builds in these areas as a creative, innovative and skilled labour class arrived looking for an urban lifestyle.

Due to the success of many well-known urban transformations showcased by our cities, their population now expects these areas to address and overcome many contemporary urban challenges like unemployment, changing demographics, complex mobility demands, stagnating economies and even climate change.

\section{Ensuring Longevity}

The redevelopment of brownfield sites mostly means increasing the density of uses and people. But simply increasing the density of cities has substantial implications for society, often adding strain to public services that are already pushed to their limits.

One of the questions related to the liveability of our cities is: "What are the limits of urban density?" Will history repeat itself and will we once again abandon our city cores because they are overcrowded, unhealthy and unsafe?

After the success stories of urban regeneration developments such as Bilbao's Ría 2000 in Spain, London's Canary Wharf and Hamburg's "Hafencity", it seems that almost every well-respected European city is looking for its own piece of the pie. 
It's no surprise, as a successful urban transformation can unlock the real value of an urban wasteland, improving the city's image and attracting new business and investment. The cited examples prove that they can boost culture, architecture, art and innovation while offering a new "habitat" for city inhabitants and tourists alike. But what triggers regeneration and what factors make them a success or a failure? These questions are especially pertinent in Eastern Europe, where the need for a renewed economic boost in cities is even greater than in Central Europe.

\section{Designing for Communities}

One of the most important factors of success is recognising the complexity of these developments - more often than not, the larger the project, the greater the number of challenges. And much like a biological ecosystem, a city's urban tissue is enormously complex, with many stakeholders, existing infrastructures, site contamination, public and private collaborations, planning procedures and financing formulas.

The Serbian capital of Belgrade in Eastern Europe is one of considerable sensitive complexity, as the country transitions from a history of changing legal frameworks, complicated approval processes and large public companies with somewhat rigid regulations into a new socio-economic context with renewed rules and regulations.

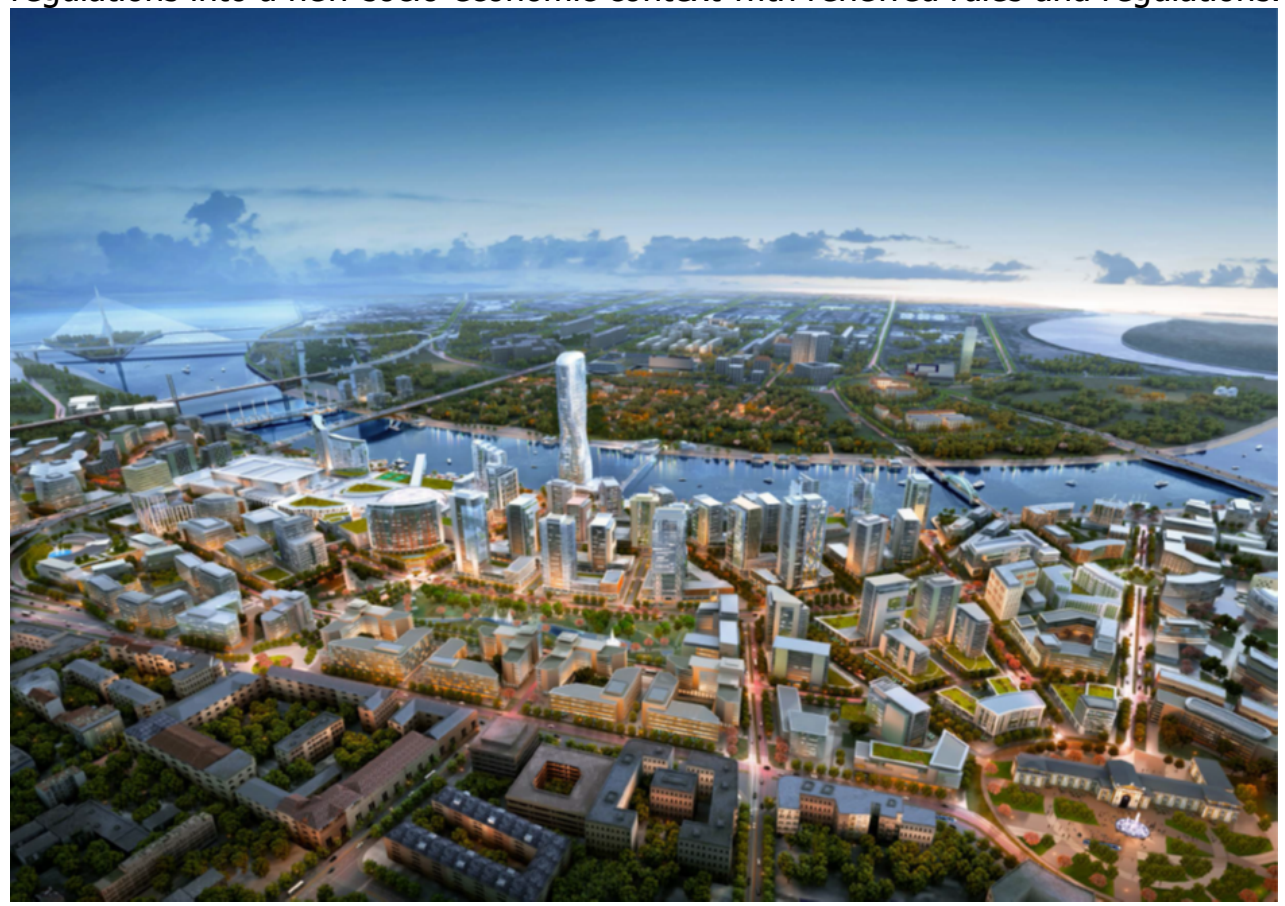

Image 1; Rendered perspective of the Concept Masterplan Belgrade Waterfront.

Our masterplan design for a 100-hectare contemporary waterfront site is having to address these issues, but most importantly it must also address some important social and cultural differences while informing a population eager to exercise its newly gained democratic rights. In this case, urban design should be for and with the people. In response, our masterplan provides accessible and high quality, diverse public community spaces to turn an inhospitable ship breaking yard into a two kilometre publicly accessible multifunctional waterfront. It also reconverts industrial heritage as central cultural spaces in the spatial structure. 
The Masterplan can be explained as a spatial framework of multiple conceptual layers that are interconnected, each one of which addresses specific aspects of social and cultural life and wellbeing of its future population, as well as its visitors. The image below shows five of many more of those layers.

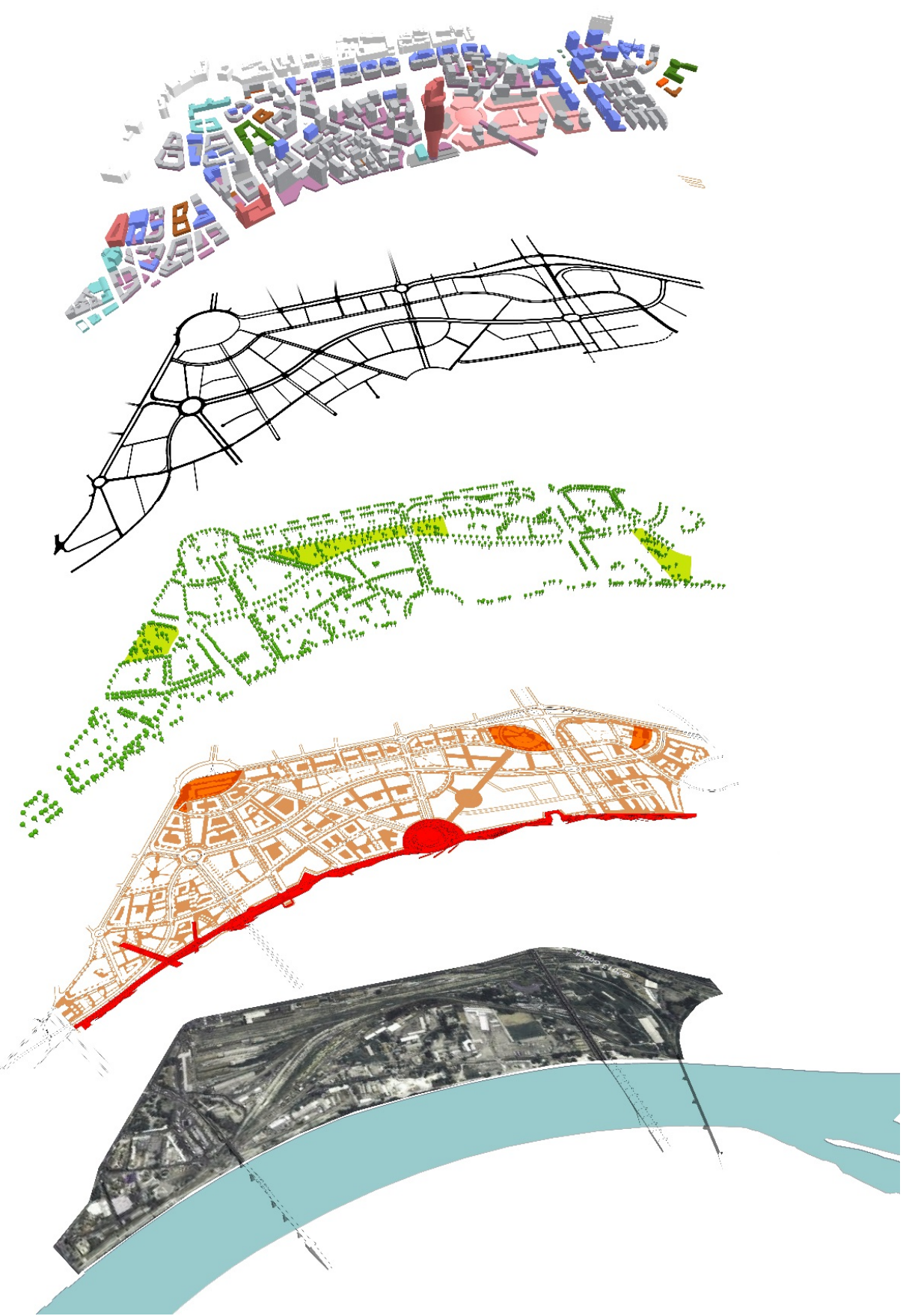

Image 2; Layers diagram of the Concept Masterplan for Belgrade Waterfront. 
The first layer reveals the "genius loci". Existing urban surroundings and site conditions offer many opportunities to create civic, cultural and historic landmarks from cultural and industrial heritage like railway buildings, train tracks and bridges. They are carefully integrated on key locations in the new spatial structure, ready to fulfil a new role in the community. The second layer shows the importance of creating places. Memorable, recognizable and attractive places are the heart of the community because it is where people meet, play, talk, express themselves, walk, rest, etc. The Sava waterfront represents the place where city and nature meet. Urban landscape is the layer that improves the urban climate and celebrates the seasons. The urban realm is structured by a "green" network. The forth layer sets the parameters for a sustainable mobility model with a walkable community at the centre. This is achieved by a fine-grained network and a high intensity of uses and activities. Finally a mixed community is created by a three dimensional layer of a high density mix of uses, functions and activities. A vibrant community where you can live, work and play can only be achieved by combining horizontal zoning with a vertical mix of uses.

Working in the heart of the city means working with the identity and the "genius loci" of the site, which remains in the hearts and memories of many citizen.

In the heart of the "Old Continent", at the Tor di Valle-Stadio della Roma development, our Masterplanning team is using sports and entertainment as the key drivers of urban regeneration on a 125-hectare abandoned site along the Tiber River. The mixed-use district will combine advanced sporting facilities - including AS Roma's new football stadium - a business park with three iconic office towers, public parks and the "Convivium" entertainment district. In this case, the urban design for the central "Convivium" district explores the use of two classic pieces of urban realm; the street and the square. The spatial configuration of the built program and public spaces is intended to create a destination for visitors, workers, citizens and tourists that extends and integrates the use of the surrounding districts.

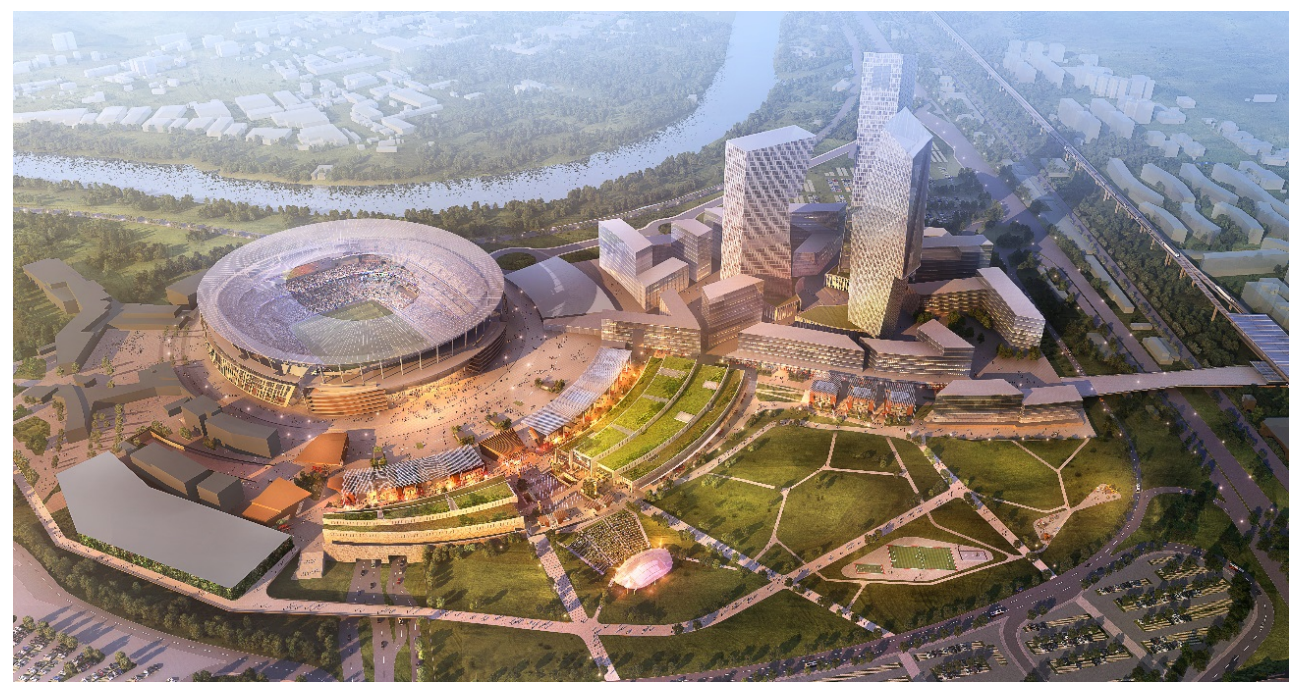

Image 3; Rendered view of the Stadio della Roma "Convivium" Masterplan. 

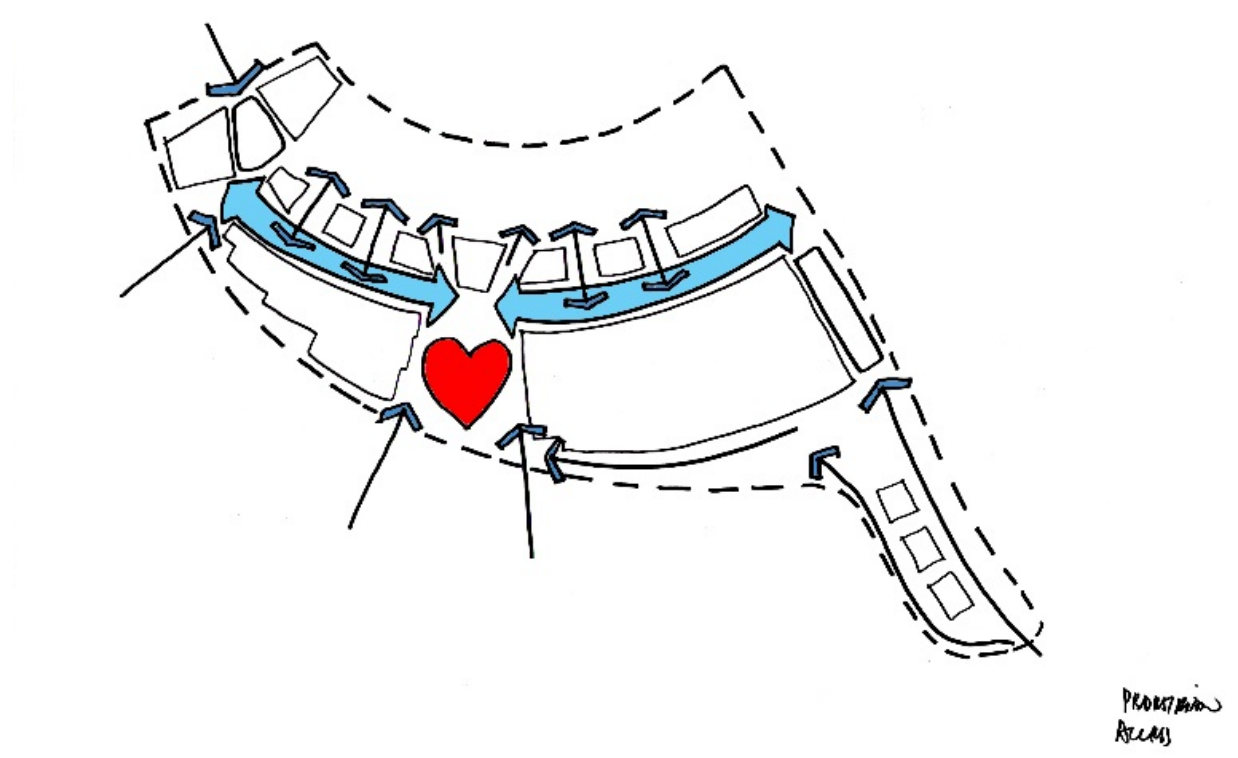

Image 4; Space diagram of Stadio della Roma "Convivium" Masterplan.

\section{Vision for the Future}

While the way in which we live, work and play has changed, people are still looking for vibrant communities that combine the essentials they need with amenities they want. From Rome to Belgrade, the invaluable and essential power of human involvement is evident in every successful urban regeneration project. When redeveloping widely used civic spaces, deeply embedded in the hearts and minds of people and communities, it is imperative that urban design professionals get this right. Identifying the most important factor is the easy bit. It's making it work that's the challenge.

\section{REFERENCES}

[1] Reference 1. Image 1. Rendered perspective of the Concept Masterplan Belgrade Waterfront.. Copy Right RTKL ME-Ltd. Client; Eagle Hills

[2] Reference 2. Image 2. Layers diagram of the Concept Masterplan for Belgrade Waterfront.. Copy Right RTKL ME-Ltd. Client; Eagle Hills

[3] Reference 3 Image 3. Rendered view of the Stadio della Roma "Convivium" Masterplan, Copy Right RTKL UK Ltd. Client; Stadio della Roma

[4] Reference 4 Image 4. Space diagram of Stadio della Roma "Convivium" Masterplan, Copy Right RTKL UK Ltd. Client: Stadio della Roma

Article distributed under a Creative Commons AttributionNonCommercial-NoDerivatives 4.0 International License (CC BY-NC-ND). Received October 20, 2015

Accepted October 22, 2015 